\title{
Development of E-Commerce for Selling Honey Bees in the COVID-19 Era
}

\author{
Indriani $^{1 *}$, Muhammad Halmi Dar ${ }^{2)}$, Irmayanti ${ }^{3)}$ \\ ${ }^{122) 3}$ Universitas Labuhanbatu, Indonesia \\ 1)iindri069@gmail.com, ${ }^{2)}$ mhd.halmidar@gmail.com, ${ }^{3)}$ irmayantiritonga2@gmail.com
}

Submitted : Jan 1, 2022 | Accepted : Jan 17, 2022 | Published : Jan 19, 2022

\begin{abstract}
During the Covid-19 pandemic, which has not yet ended, the business of selling honey is a type of business that is able to survive and even increase its market. The trend of selling honey in the era of the Covid-19 pandemic is quite stable and has the potential to be a good source of income because honey can be used as medicine and can increase the body's immunity. Fitorajo Bee Farm is a UMKM engaged in bee cultivation which is located in Kota Pinang, Labuhanbatu Selatan Regency, North Sumatra Province with original honey bee products packaged in plastic bottle containers. The marketing system carried out by Fitorajo Bee Farm is carried out through word of mouth, Facebook social media, or through the WhatsApp application. Seeing the promising potential of the honey business in the Covid-19 pandemic era, and in order to reach a wider market, Fitorajo Bee Farm should improve and innovate by adopting e-commerce technology. Conventional marketing, which so far only reaches consumers on a limited scale, must be changed with a marketing system that can reach consumers from any corner. The purpose of this research is to build a marketing media for Fitorajo Bee Farm honey bees by implementing web-based e-commerce. The system development method used is the waterfall model, while the programming language used is PHP framework codeigniter with MySQL DBMS. The results showed that the codeigniter framework and MySQL DBMS can be applied to build e-commerce web-based honey bee marketing media.
\end{abstract}

Keywords: COVID-19; Codeigniter; E-Commerce; Honey; UMKM, UML.

\section{INTRODUCTION}

Covid-19 is a virus that was first discovered in an animal and food market in Wuhan City, Hubei Province, China (Hidayat, Aini, Ilmi, Azzahroh, \& Giantini, 2020). On March 12, 2020, the World Health Organization (WHO) declared Covid-19 a global pandemic (Ophinni et al., 2020). Covid-19 first appeared in Indonesia on March 2, 2020 with the findings of two cases of infection (R. N. Putri, 2020). As of June 19, 2021, the number of people who have been confirmed positive for Covid in Indonesia is more than 1.9 million, and the death toll is more than 54 thousand people (Kementerian Kesehatan Republik Indonesia, 2021).

The Covid-19 pandemic not only resulted in a health crisis, but this outbreak also had a negative impact on the Indonesian economy (Yenti Sumarni, 2020) (Nasution, Erlina, \& Muda, 2020) (Wahidah, Septiadi, Rafqie, Hartono, \& Athallah, 2020), especially in the tourism, transportation, health, and trade sectors (Susilawati, Falefi, $\&$ Purwoko, 2020). The social distancing policy during the pandemic has resulted in significant national economic losses, the real impact of losses for business entities is the loss of income due to the absence of sales, while the expense burden remains (Hadiwardoyo, 2020). One of the business sectors that is very vulnerable to bankruptcy due to the Covid-19 pandemic is the Usaha Mikro Kecil dan Menengah (UMKM) sector (Iskandar, Possumah, \& Aqbar, 2020). Due to Covid-19, sales of the UMKM sector in Indonesia have decreased, it is difficult to receive capital assistance, product distribution is hampered, and raw materials are scarce (Sugiri, 2020).

The strategy that can be used in an effort to save UMKM is to build business processes based on digital technology platforms (Sugiri, 2020). This is proven by the increase in sales volume through electronic transactions (e-commerce) during the pandemic because consumers feel safer, more effective and efficient by shopping online (Ayu \& Lahmi, 2020). With the implementation of the health protocol, UMKM actors seem to be forced to adopt e-commerce because inevitably business actors have to change the way they transact from offline to online

*name of corresponding author 
(Kala'lembang, 2020) (Sumarni \& Melinda, 2020). E-Commerce is recommended as a strategy in maintaining UMKM during the Covid-19 pandemic (Hardilawati, 2020).

During the Covid-19 pandemic, which has not yet ended, the business of selling honey is a type of business that is able to survive and even increase its market. The trend of selling honey in the Covid-19 pandemic era is quite stable and has the potential to be a good source of income because honey can be used as medicine and can increase body immunity (Okezone, 2020) (Rakyat, 2021). The beekeeping business is a potential business sector in the Covid-19 pandemic (UNPAD, 2020). Even UMKM with honey businesses are able to expand their market online to overseas in the midst of the Covid-19 pandemic (Maskur, 2021). The trend of selling honey through the Tokopedia e-commerce application has also increased two to three times compared to before the Covid-19 pandemic (TEMPO, 2020) (6, 2020) (I. Putri, 2021).

Fitorajo Bee Farm is an UMKM engaged in bee cultivation located in Kota Pinang, Labuhanbatu Selatan Regency, North Sumatra Province. The product from Fitorajo Bee Farm is real honey bees packaged in plastic bottles. The marketing systems carried out by Fito-rajo Bee Farm are carried out through word of mouth, Facebook social media, or through the WhatsApp application. Meanwhile, business transactions are usually carried out by making payments directly or through ATMs. Direct payments are made when consumers come directly to the location to buy honey, while payments through ATMs are made if consumers order via Facebook or WhatsApp.

Seeing the promising potential of the honey business in the Covid-19 pandemic era, and in order to reach a wider market, Fitorajo Bee Farm should clean up and innovate by adopting e-commerce technology in marketing honey in the era of the Covid-19 pandemic. don't know when it will end. Conventional marketing, which has only reached consumers on a limited scale, must be changed to a marketing system that can reach consumers from all over. The purpose of this research is to develop a marketing media for Fitorajo Bee Farm honey bees by implementing web-based e-commerce.

\section{LITERATURE REVIEW}

E-Commerce is a business transaction process that is run electronically through the use of computers and internet networks (Wibowo \& Haryokusumo, 2020) (Andriyanto, 2018). The advantages of e-commerce compared to conventional marketing systems lie in a wide marketing reach, minimal product promotion costs, ease of conducting transactions and making sales and purchase reports (S \& Sari, 2020).

Codeigniter is a PHP framework whose development is oriented to the concept of Model View Controller (MVC). Codeigniter has a complete library to perform operations commonly required by web-based applications, such as accessing databases, validating forms so that the system developed is easy. Codeigniter is also the only framework with complete and clear documentation. The program code in the CodeIgniter framework is equipped with comments in it so that it further clarifies the function of a program code and the resulting Codelgniter is very clean and Search Engine Friendly (SEF) (Destiningrum \& Adrian, 2017).

Unifield Modeling Language (UML) is a visual modeling method used in the design and manufacture of objectoriented software. UML is a writing standard or a kind of blueprint which includes a business process, writing classes in a specific language (Prihandoyo, 2018). UML was created to provide the tools needed by software developers in analyzing, designing and implementing software-based systems (Kurniawan, 2018). There are several UML diagrams that are often used in the development of a system, namely: use case diagrams, activity diagrams, sequence diagrams, and class diagrams (Primadasa \& Juliansa, 2020).

\section{METHOD}

This study uses the System Development Life Cycle (SDLC) software development method by choosing the waterfall model. The waterfall model applies a sequential approach and is easy to implement in making the system (Nurjannah, Dar, \& Bangun, 2021). The process in the waterfall model starts from requirements analysis, system design, implementation, testing, and maintenance (Aldi, 2022). Web-based E-Commerce application development is currently using the PHP framework. There are several reasons why the Codeigniter framework is used in building e-commerce applications in this research. First of all, the framework can increase productivity in programming because the framework provides a basic framework (Model, View and Controller), a complete Application Programming Interface and Library so that web developers don't need a long time to code (Laaziri, Benmoussa, Khoulji, \& Kerkeb, 2019). Second, the built-in documentation support available from many frameworks and forums on the internet makes web developers faster in finding answers when facing error programs (Benmoussa, Laaziri, Khoulji, Larbi, \& Yamami, 2019). Third, the framework has advantages in terms of web security (Lakshmi \& Mallika, 2017). In testing the performance of some of the most frequently used PHP frameworks, it was found that Co-deigniter is superior to the Symfony framework in several criteria required for a Model View Controller (MVC) based framework (Laaziri et al., 2019). Viewed from the security aspect, the use of codeigniter is safer than PHP Native (Yaqin \& Al Anis, 2018) because the user is not directly related to the

*name of corresponding author 
database (Somya, 2018). The Codeigniter framework is open-source, so it does not require a fee in terms of license usage (Vidal-Silva, Jiménez, Madariaga, \& Urzúa, 2020). The most popular thing about the Codeigniter framework is its very fast execution time compared to other frameworks (Saputra et al., 2020).

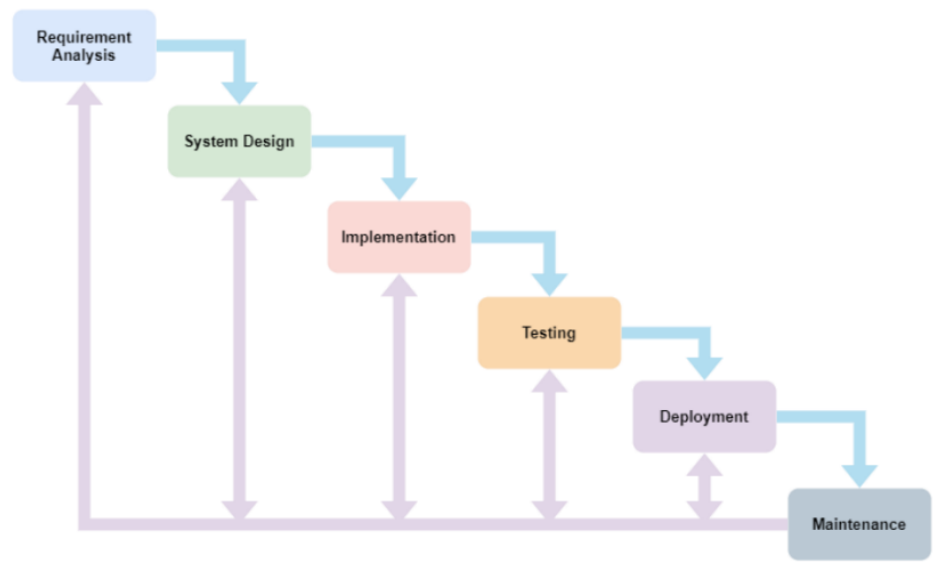

Fig. 1 Software Development Method

\section{Requirement Analysis}

This stage is the initial activity in creating an e-commerce web. At this stage, the needs that will be provided by the e-commerce web are determined, the information needs available on the website, the type of user and access rights, software and hardware requirements. The data collection method used in this research is literature study and observation. Literature studies are obtained from studying books or written materials such as journals that have to do with the research being carried out. Observation, namely data collection techniques carried out through field observations of the research object. In addition, data about the products to be sold is obtained from direct interviews with sources. The things that must be analyzed against the needs of this system are: First, how to manage category data and item data. Second, how to verify orders made by users. Third, how to manage order data and delivery data. Fourth, the process of making reports

\section{System Design}

At this stage, software and website design are carried out according to the needs obtained from the needs analysis. The system design uses the Unified Modeling Language modeling language in the form of Use Case Diagrams and Activity Diagrams.

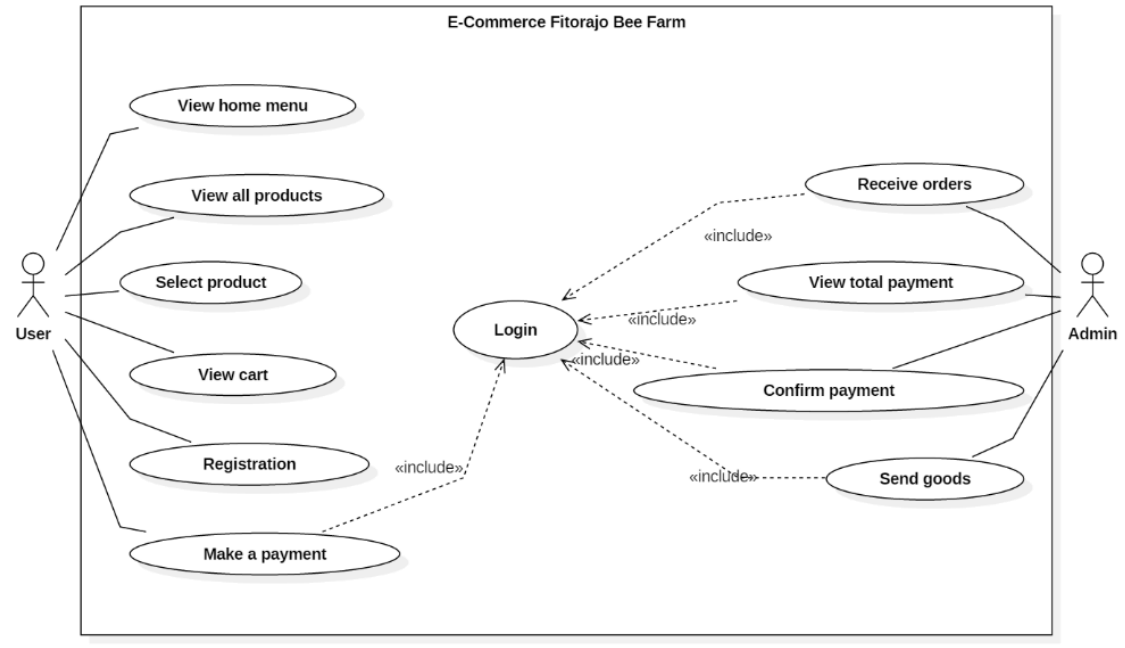

Fig. 2 Use Case Diagram

Based on the use case diagram in Figure 2, there are two actors involved in the system with different access rights, namely Admin and User. Admin has full access rights to the system in processing user data, and processing report data. Meanwhile, the user can only register and order goods.

*name of corresponding author 


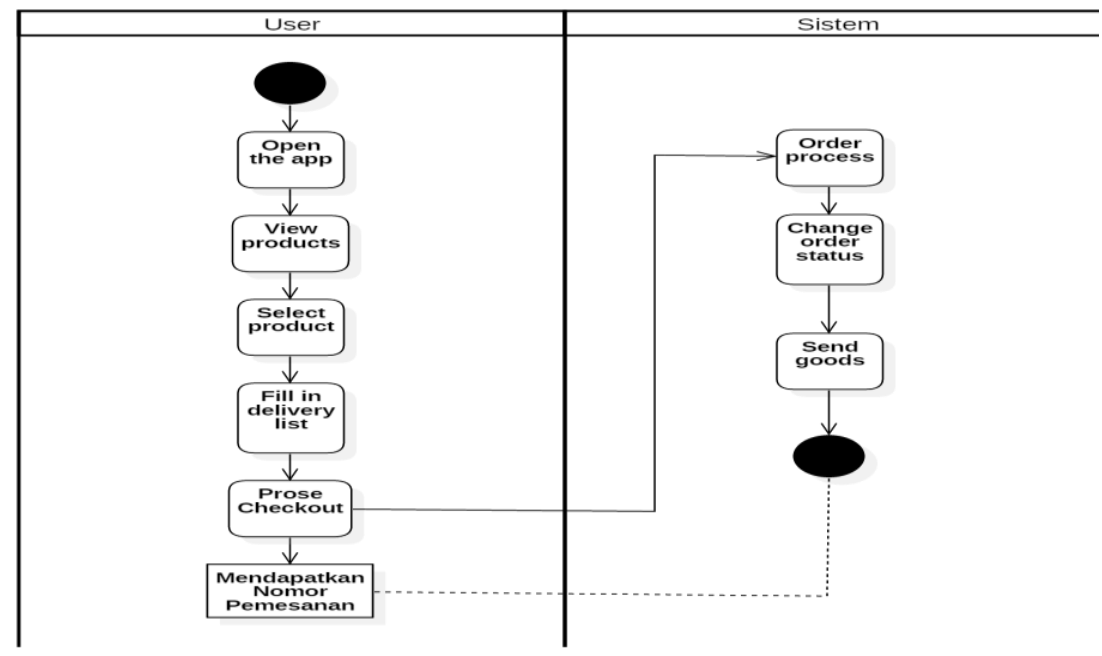

Fig. 3 Activity Diagram

The Activity diagram in Figure 3 shows how the process of ordering honey bee products is carried out. After the user opens the application, the user can select the desired product, then register and place an order for goods. The system in the application will change the order status after the user confirms the payment.

\section{Implementation}

At this stage, the design that has been made is implemented. The database is implemented using the MySQL DBMS, and the coding of the program uses the PHP Codeigniter Framework.

\section{Testing}

Testing is done by testing the functionality of the software that has been implemented. Testing using the Blackbox Testing method.

\section{Maintenance}

After testing the software, then routine maintenance is carried out on the software. Routine maintenance is carried out to prevent errors from occurring that cause system disturbances.

\section{RESULT}

After the design and system testing stages were carried out, it was found that what was designed was in accordance with what was shown. While in the testing process, the tested components can function properly. The system process that runs is the user opens the application then selects an item, then the system accepts the user's choice and will automatically enter the user's shopping cart, then the system calculates the total purchase automatically. The user will receive the total transaction then complete the transaction data and then pay according to the calculated amount, after the user makes the payment, the system will automatically confirm. Then the store admin will process the delivery of goods.

In the implementation of e-commerce to market honey, there is a main menu where users can see the benefits of honey itself and can see various honey products. After the user sees the various honey products on the website, then wants to buy it, the user can immediately choose the honey as desired. After selecting the honey, the website will display the details of the selected honey, then the buyer can process the purchase by viewing the basket and then clicking checkout process. Then the buyer is asked to write down personal data and choose a payment method then the buyer can make a payment according to the method that has been previously selected. After making the payment, the buyer can confirm the payment. There are admin activities, namely inputting category and item data, viewing customer data, viewing orders and changing order status if the customer has made a payment, can also view reports, namely stock of goods, orders, \& delivery. 


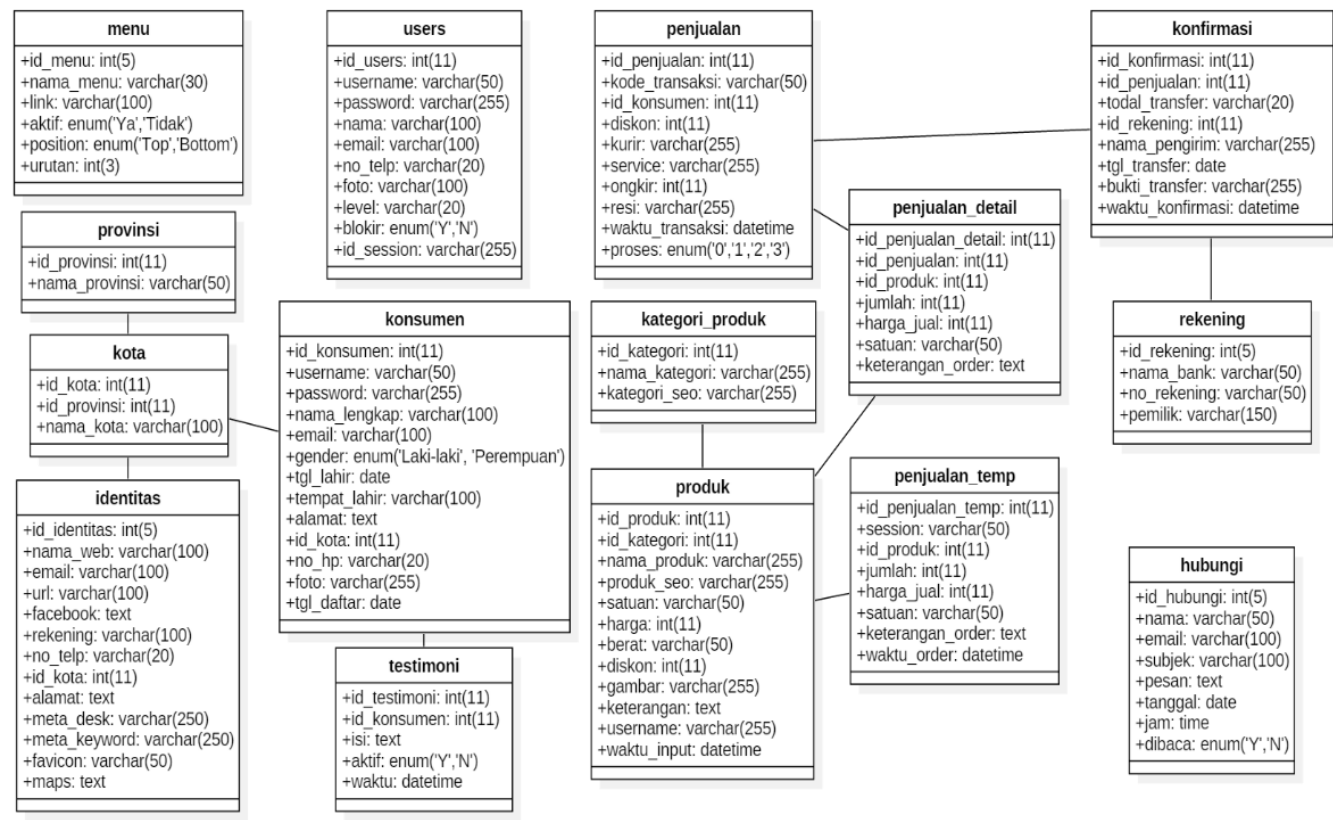

Fig. 4 Class Diagram

The class diagram in Figure 4 shows the schema of the relationship between tables in the e-commerce that was built. Some bolds have relationships with other tables.

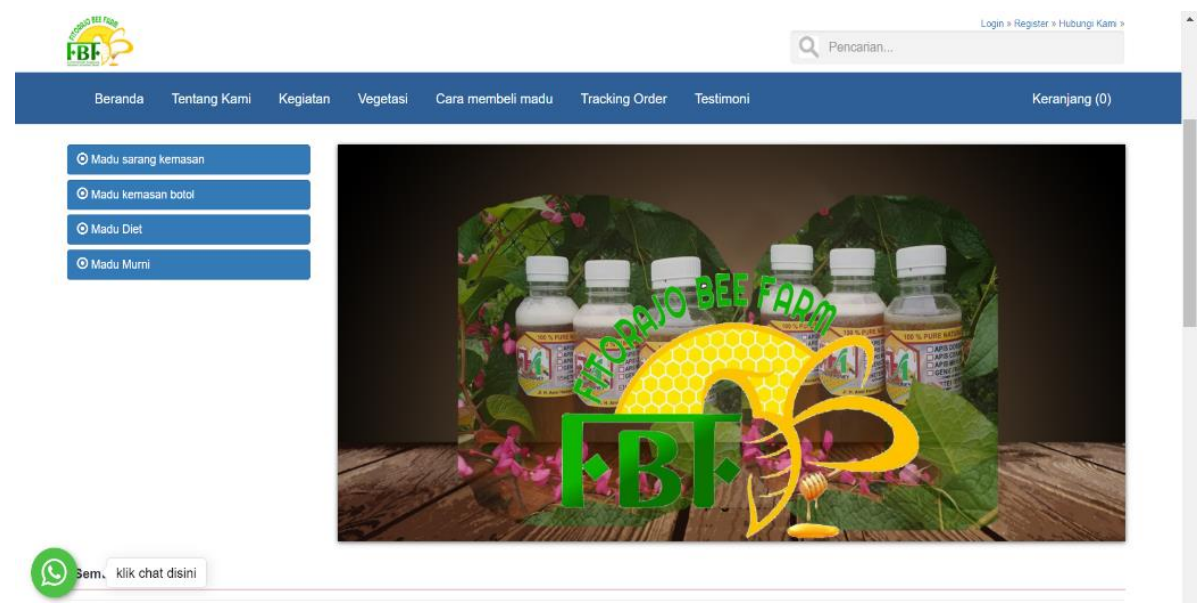

Fig. 5 Home Page

The home page shows the types of honey bee products. Each visitor can see the desired honey bee product and can also place an order. 


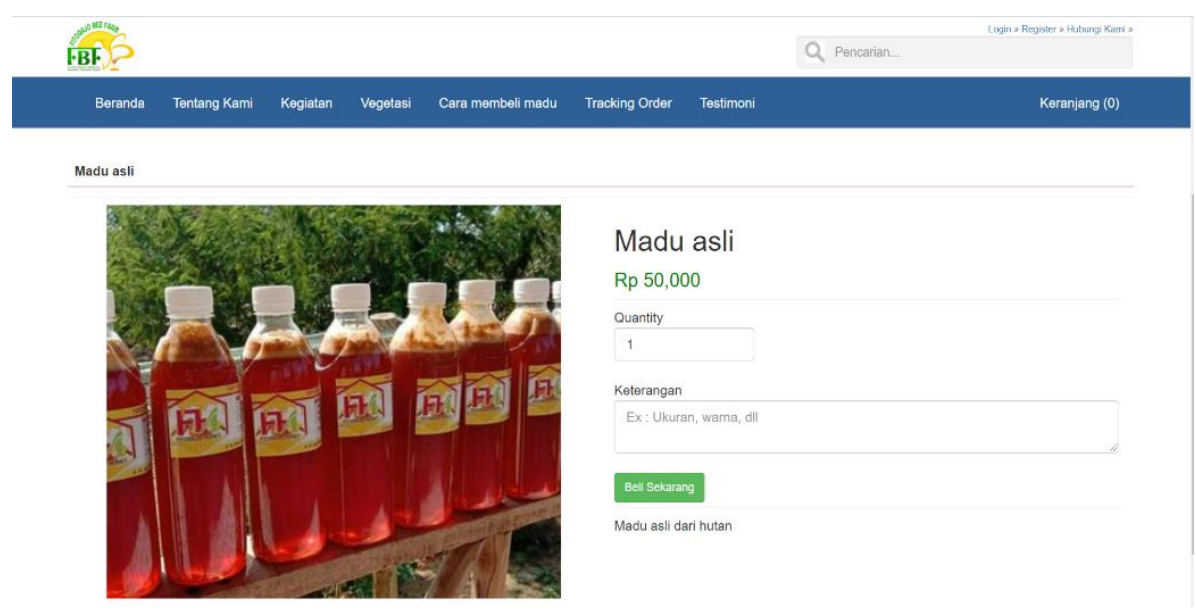

Fig. 6 Order Page

on the product ordering page, visitors can place an order according to the type of product and the desired number of items.

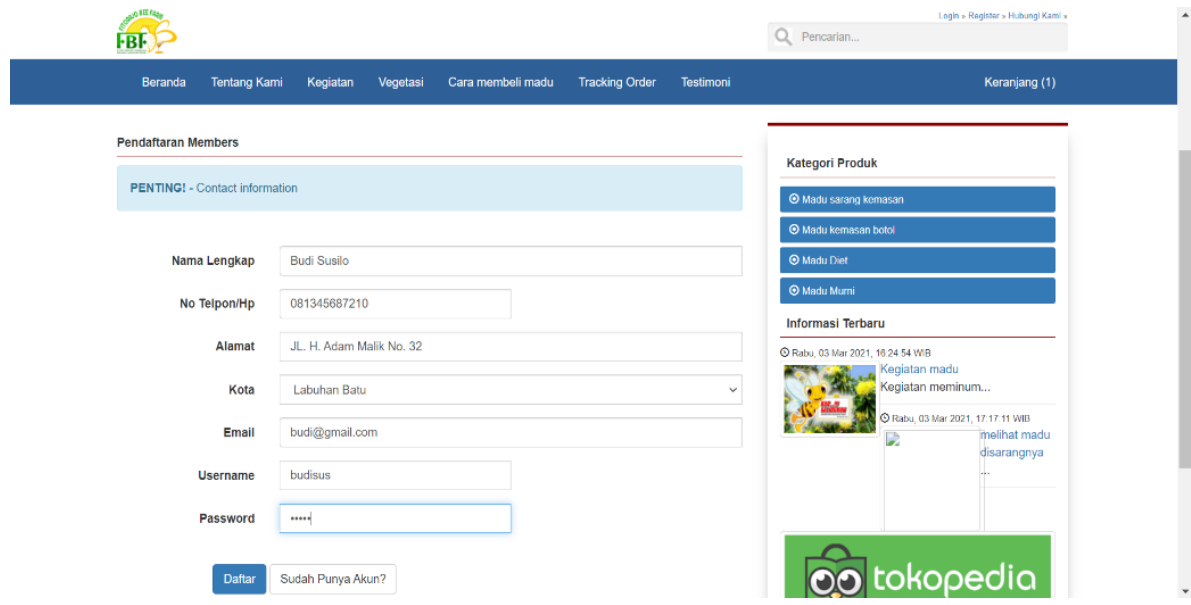

Fig. 7 Registration Page

After ordering the product, the buyer must register by entering personal data. This process is so that the system can confirm the order made by the user.

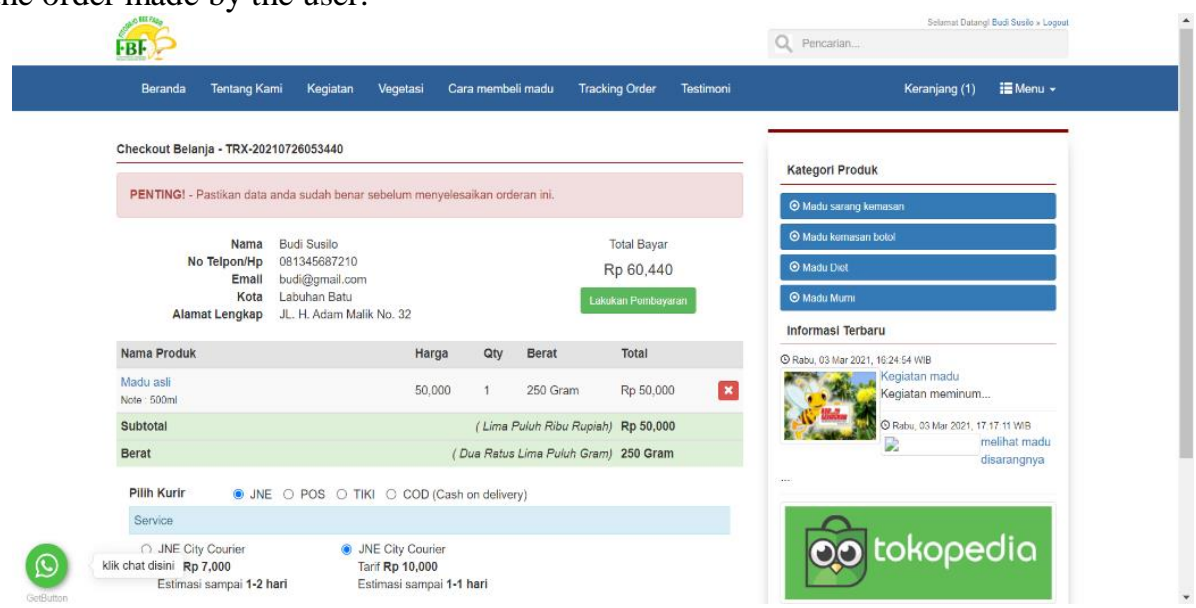

Fig. 8 Payment Page

*name of corresponding author 


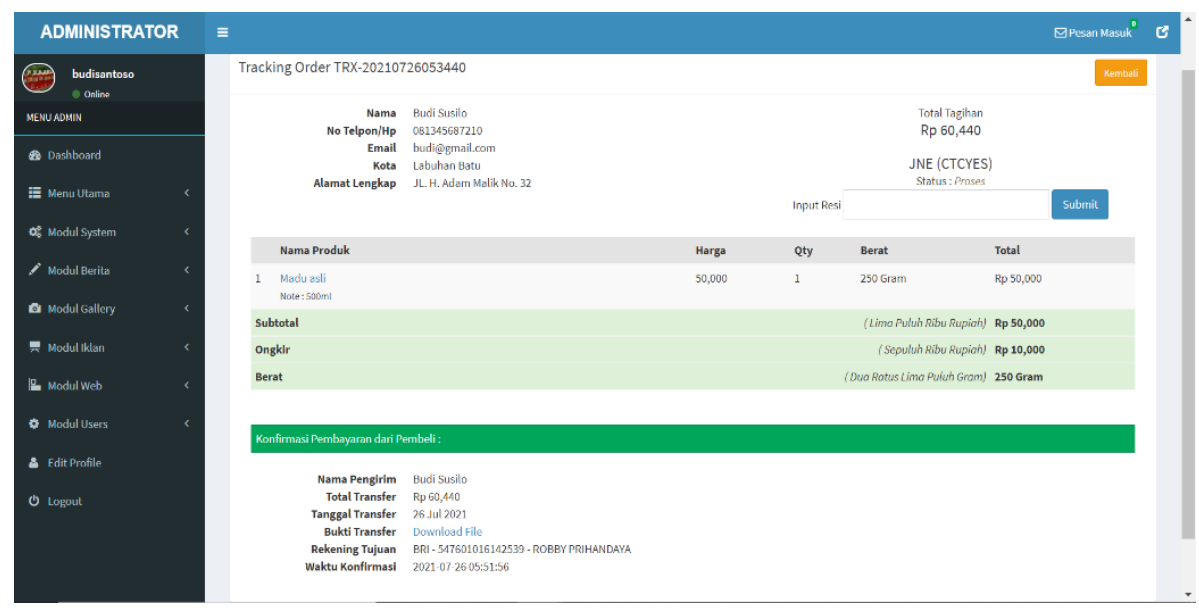

Fig. 9 Ship Items Page

Figures 8 and 9 describe the process of payment and delivery of goods. On the payment page (fig. 7), the user must see in detail the personal identity and product ordered before making a payment. This page also specifies the type of shipping company you want and the type of package you choose. While in Figure 8, the system has confirmed the payment that has been made by the user for further delivery of goods through the choice of the delivery company that has been determined.

Table 1. Transactions Report

\begin{tabular}{|c|c|c|c|c|c|c|}
\hline No. & $\begin{array}{c}\text { Transaction } \\
\text { Code }\end{array}$ & $\begin{array}{c}\text { Shopping } \\
\text { Amount }\end{array}$ & Delivery & Destination & Time & Status \\
\hline 1 & $\begin{array}{c}\text { TRX- } \\
20210726053440\end{array}$ & Rp. 60,440 & $\begin{array}{c}\text { JNE } \\
\text { (CTCYES) }\end{array}$ & Labuhanbatu & $\begin{array}{c}2021-07-26 \\
05: 44: 48\end{array}$ & Confirmed \\
\hline 2 & $\begin{array}{c}\text { TRX- } \\
20210716143825\end{array}$ & Rp. 300,826 & JNE (CoD) & Labuhanbatu & $\begin{array}{c}2021-07-16 \\
14: 39: 59 \\
\end{array}$ & Confirmed \\
\hline 3 & $\begin{array}{c}\text { TRX- } \\
20210712093321\end{array}$ & Rp. 70,322 & JNE (CoD) & Labuhanbatu & $\begin{array}{c}2021-07-12 \\
09: 36: 45\end{array}$ & Pending \\
\hline 4 & $\begin{array}{c}\text { TRX- } \\
20210301212847\end{array}$ & Rp. 721,847 & TIKI (REG) & Labuhanbatu & $\begin{array}{c}\text { 2021-03-01 } \\
21: 29: 23\end{array}$ & Pending \\
\hline 5 & $\begin{array}{c}\text { TRX- } \\
20210301184009\end{array}$ & Rp. 1,771,009 & TIKI (REG) & Labuhanbatu & $\begin{array}{c}\text { 2021-03-01 } \\
18: 43: 33\end{array}$ & Pending \\
\hline
\end{tabular}

Table 1 shows a report page that records all purchase transaction processes that have been carried out by users. This page will display all types of transactions (confirmed or pending) according to the total spent and the time of the transaction.

Table 2. Blackbox Testing Result

\begin{tabular}{lll}
\hline Scenario & Expected Results & Result \\
\hline Click the home menu & The system displays the home menu & Success \\
\hline Click the menu about us & The system displays a menu about us & Success \\
\hline Click product menu & System displays all honey products & Success \\
\hline Click add cart & The system displays the add cart menu & Success \\
\hline Click view cart & The system displays the product purchase cart & Success \\
\hline Click checkout & $\begin{array}{l}\text { The system displays the checkout menu then fills in } \\
\text { your personal data and makes a payment }\end{array}$ & Success \\
\hline
\end{tabular}

*name of corresponding author 
Testing with the blackbox testing method is carried out by carrying out several test scenarios for the menu button functionality. Furthermore, the expected results are compared with the actual results. If there is a match between the expected results and the actual results, then the test results are categorized as successful.

\section{DISCUSSIONS}

Based on the results of testing and implementation that have been described above. Testing using blackbox testing with system functional methods on the Fitorajo Bee Farm e-commerce web went well and there were no errors. With that produced an e-commerce application with the interface described above. All the interfaces described above are original images of the website that have been created by the author. All interfaces are made as simple as possible, to make it easier for potential buyers to use e-commerce websites. Also admin convenience in stock management, because e-commerce websites use the codeigniter framework. Admin can see all order reports after the buyer makes a transaction. After that, the admin can also update the buyer's order status so that buyers can see the status of their orders in real time.

The CodeIgniter framework can be applied to a web-based Fitorajo Bee Farm e-commerce system. The use of codeigniter is very helpful in writing program code because the MVC concept in the codeigniter framework makes the program code more structured and can shorten the time of the program code generation process.

\section{CONCLUSION}

Research has succeeded in building a marketing media for Fitorajo Bee Farm honey bees by implementing web-based e-commerce. The results showed that the Codeigniter framework and MySQL DBMS can be applied to build e-commerce web-based honey bee marketing media.

\section{REFERENCES}

6, L. (2020). 5 Jenis Makanan dan Minuman yang Paling Dicari di Mada Pandemi. Retrieved July 7, 2021, from liputan6.com website: https://www.liputan6.com/lifestyle/read/4361173/5-jenis-makanan-dan-minumanyang-paling-dicari-di-masa-pandemi

Aldi, F. (2022). Web-Based New Student Admission Information System Using Waterfall Method. SinkrOn, 7(1), 111-119. https://doi.org/https://doi.org/10.33395/sinkron.v7i1.11242

Andriyanto, I. (2018). Penguatan Daya Saing Usaha Mikro Kecil Menengah Melalui E-Commerce. BISNIS: Jurnal Bisnis Dan Manajemen Islam, 6(2), 87-100. https://doi.org/http://dx.doi.org/10.21043/bisnis.v6i2.4709

Ayu, S., \& Lahmi, A. (2020). Peran e-commerce terhadap perekonomian Indonesia selama pandemi Covid-19. Jurnal Kajian Manajemen Bisnis, 9(2), 114-123. https://doi.org/10.24036/jkmb.10994100

Benmoussa, K., Laaziri, M., Khoulji, S., Larbi, K. M., \& Yamami, A. El. (2019). A new model for the selection of web development frameworks: application to PHP frameworks. International Journal of Electrical and Computer Engineering (IJECE), 9(1), 695. https://doi.org/10.11591/ijece.v9i1.pp695-703

Destiningrum, M., \& Adrian, Q. J. (2017). SISTEM INFORMASI PENJADWALAN DOKTER BERBASSIS WEB DENGAN MENGGUNAKAN FRAMEWORK CODEIGNITER ( STUDI KASUS: RUMAH SAKIT YUKUM MEDICAL CENTRE ). TEKNOINFO, 11(2), 30-37.

Hadiwardoyo, W. (2020). Kerugian Ekonomi Nasional Akibat Pandemi Covid-19. Baskara: Journal of Business and Entrepreneurship, 2(2), 83-92. https://doi.org/10.24853/baskara.2.2.83-92

Hardilawati, W. L. (2020). Strategi Bertahan UMKM di Tengah Pandemi Covid-19. Jurnal Akuntansi Dan Ekonomika, 10(1), 89-98. https://doi.org/10.37859/jae.v10i1.1934

Hidayat, R., Aini, N., Ilmi, A. F. N., Azzahroh, F., \& Giantini, A. (2020). Test, Trace, and Treatment Strategy to Control COVID-19 Infection Among Hospital Staff in a COVID-19 Referral Hospital in Indonesia. Acta Medica Indonesiana, 52(3), 206-213.

Iskandar, A., Possumah, B. T., \& Aqbar, K. (2020). Peran Ekonomi dan Keuangan Sosial Islam Saat Pandemi Covid-19. SALAM: Jurnal Sosial Dan Budaya Syar-I, 7(7), $625-638$. https://doi.org/10.15408/sjsbs.v7i7.15544

Kala'lembang, A. (2020). Adopsi E-Commerce Dalam Mendukung Perkembangan Usaha Mikro Kecil dan Menengah (UMKM) di Masa Pandemi Covid-19. JCAPITAL Jurnal Ekonomi Dan Manajemen, 4(1), 5465.

Kementerian Kesehatan Republik Indonesia. (2021). Situasi Terkini Perkembangan Coronavirus Disease (COVID-19). In Kemenkes Republik Indonesia. Jakarta. Retrieved from https://covid19.kemkes.go.id/download/Situasi_Terkini_050520.pdf

Kurniawan, T. A. (2018). Pemodelan Use Case (UML): Evaluasi Terhadap beberapa Kesalahan dalam Praktik. Jurnal Teknologi Informasi Dan Ilmu Komputer, 5(1), 77. https://doi.org/10.25126/jtiik.201851610

Laaziri, M., Benmoussa, K., Khoulji, S., \& Kerkeb, M. L. (2019). A Comparative study of PHP frameworks

*name of corresponding author 
performance. Procedia Manufacturing, 32, 864-871. https://doi.org/10.1016/j.promfg.2019.02.295

Lakshmi, D. R., \& Mallika, S. S. (2017). A Review on Web Application Testing and its Current Research Directions. International Journal of Electrical and Computer Engineering (IJECE), 7(4), 2132-2141. https://doi.org/10.11591/ijece.v7i4.pp2132-2141

Maskur, F. (2021). Pandemi Covid-19, Rumah Madu Hutan Jambi Go-International. Retrieved July 7, 2021, from Bisnis.com website: https:/ekonomi.bisnis.com/read/20210219/257/1358621/pandemi-covid-19-rumahmadu-hutan-jambi-go-international

Nasution, D. A. D., Erlina, \& Muda, I. (2020). Dampak Pandemi COVID-19 terhadap Perekonomian Indonesia. Jurnal Benefita, 5(2), 212-224. https://doi.org/10.36423/jumper.v2i2.665

Nurjannah, Dar, M. H., \& Bangun, B. (2021). Sistem Pelacakan Kontak COVID-19 Menggunakan Teknologi QR Code Berbasis Web. JURTEKSI (Jurnal Teknologi Dan Sistem Informasi), 7(3), $283-292$. https://doi.org/https://doi.org/10.33330/jurteksi.v7i3.1180

Okezone. (2020). Penjualan Madu Botolan Laris Manis saat Pandemi Covid-19. Retrieved July 7, 2021, from okezone.com website: https://economy.okezone.com/read/2020/09/20/455/2280781/penjualan-madubotolan-laris-manis-saat-pandemi-covid-19?page=1

Ophinni, Y., Hasibuan, A. S., Widhani, A., Maria, S., Koesnoe, S., Yunihastuti, E., ... Djauzi, S. (2020). COVID19 Vaccines : Current Status and Implication for Use in Indonesia. Acta Medica Indonesiana, 52(4), 388412.

Prihandoyo, M. T. (2018). Unified Modeling Language (UML) Model Untuk Pengembangan Sistem Informasi Akademik Berbasis Web. Jurnal Pengembangan IT (JPIT), 03(01), 126-129.

Primadasa, Y., \& Juliansa, H. (2020). Rancang Bangun Sistem E-Discussion Untuk Mahasiswa Kota Lubuklinggau Designing An E-Discussion System For Students Of Lubuklinggau City. 6(2), 310-322.

Putri, I. (2021). 5 Produk dan Peluang Bisnis yang Diprediksi Jadi Tren 2021. Retrieved July 7, 2021, from detikFinance website: https:/finance.detik.com/berita-ekonomi-bisnis/d-5482750/5-produk-dan-peluangbisnis-yang-diprediksi-jadi-tren-2021

Putri, R. N. (2020). Indonesia dalam Menghadapi Pandemi Covid-19. Jurnal Ilmiah Universitas Batanghari Jambi, 20(2), 705-709. https://doi.org/10.33087/jiubj.v20i2.1010

Rakyat, P. (2021). Potensi Bisnis: Budidaya Lebah Madu Peluang Usaha Menjanjikan, Simak Begini Penjelasannya. Retrieved July 7, 2021, from potensibisnis-pikiran-rakyat.com website: https://potensibisnis.pikiran-rakyat.com/umkm/pr-691434220/potensi-bisnis-budidaya-lebah-madupeluang-usaha-menjanjikan-simak-begini-penjelasannya?page $=4$

S, A., \& Sari, D. M. (2020). Implementasi Media E-Commerce Pada Pemasaran Kain Sutra Mandar Di Polewali Mandar. Jurnal Teknik Informatika Dan Sistem Informasi, 7(3), 408-415.

Saputra, D., Irmayani, W., Martias, Sidauruk, J., Haryani, Jayanti, W. E., ... Rahman, A. (2020). Application of Web-Based Competency Test (UKSI) with Framework Code Igniter (CI). International Journal of Advanced $\begin{array}{llll}\text { Science } \quad \text { and } & \text { 29(4), } & \text { 4500-4520. } & \text { Retrieved }\end{array}$ http://sersc.org/journals/index.php/IJAST/article/view/24856

Somya, R. (2018). Aplikasi Manajemen Proyek Berbasis Framework CodeIgniter dan Bootstrap di PT. Pura Barutama. Jurnal Informatika: Jurnal Pengembangan IT (JPIT), 3(2), 143-150. https://doi.org/10.30591/jpit.v3i2.726

Sugiri, D. (2020). Menyelamatkan Usaha Mikro, Kecil dan Menengah dari Dampak Pandemi Covid-19. Fokus Bisnis : Media Pengkajian Manajemen Dan Akuntansi, 19(1), $76-86$. https://doi.org/10.32639/fokusbisnis.v19i1.575

Sumarni, T., \& Melinda, L. D. (2020). Media Sosial dan E-commerce sebagai Solusi Tantangan Pemasaran Pada Masa Pandemi Covid-19 (Studi Kasus : UMKM Warung Salapan). ATRABIS: Jurnal Administrasi Bisnis, 6(2), 163-171.

Susilawati, Falefi, R., \& Purwoko, A. (2020). Impact of COVID-19's Pandemic on the Economy of Indonesia. Budapest International Research and Critics Institute (BIRCI-Journal): Humanities and Social Sciences, 3(2), 1147-1156. https://doi.org/10.33258/birci.v3i2.954

TEMPO. (2020). Madu Dalam Angka. Retrieved July 7, 2021, from majalah.tempo.com website: https://majalah.tempo.co/read/angka/161491/madu-dalam-angka

UNPAD. (2020). Menjaga Bisnis Perlebahan Tetap "Menyengat" di tengah Pandemi Covid-19. Retrieved July 7 , 2021, from unpad.ac.id website: https://www.unpad.ac.id/2020/06/menjaga-bisnis-perlebahan-tetapmenyengat-di-tengah-pandemi-covid-19/

Vidal-Silva, C., Jiménez, C., Madariaga, E., \& Urzúa, L. (2020). Applying PHP Codeigniter For Easy Web Development. International Journal of Scientific \& Technology Research, 9(3), 4209-4211.

Wahidah, I., Septiadi, M. A., Rafqie, M. C. A., Hartono, N. F. S., \& Athallah, R. (2020). Pandemik Covid-19:

*name of corresponding author 
Analisis Perencanaan Pemerintah dan Masyarakat dalam Berbagai Upaya Pencegahan. Jurnal Manajemen Dan Organisasi (JMO), 11(3), 179-188.

Wibowo, B. S., \& Haryokusumo, D. (2020). Peluang Revolusi Industri 4.0 Bidang Pemasaran: Pemanfaatan Aplikasi E-commerce, Sosial Media Instagram dan Digital Marketing terhadap keputusan Instant Online Buying Konsumen Generasi Millenial. CAPITAL, 3(2), 86-99.

Yaqin, M. A., \& Al Anis, A. (2018). Sistem Advice Planing Online Dengan Framework Codeigniter Berbasis Web Bootstrap (Studi Kasus: Kabupaten Probolinggo). Jurnal Informatika: Jurnal Pengembangan IT (JPIT), 3(2), 219-224. https://doi.org/10.30591/jpit.v3i2.842

Yenti Sumarni. (2020). Pandemi Covid-19: Tantangan Ekonomi Dan Bisnis. Al Intaj: Jurnal Ekonomi Dan Perbankan Syariah, 6(2), 46-58. 